


\title{
Effect of pods' position on the protein content in soybean grains at low latitude
}

\author{
Efeito da posição das vagens sobre o teor de proteína em grãos de soja em \\ baixa latitude
}

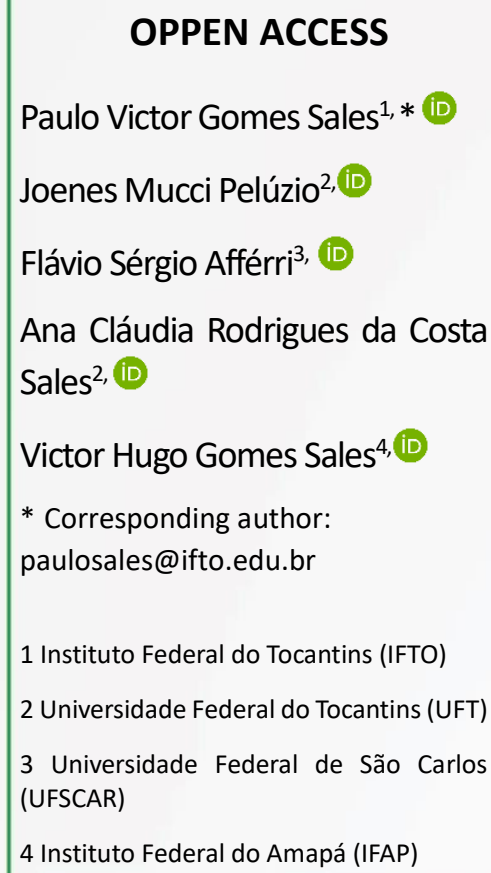

OPPEN ACCESS

Paulo Victor Gomes Sales ${ }^{1, *}$ (D)

Joenes Mucci Pelúzio 2, (iD

Flávio Sérgio Afférrii, (iD

Ana Cláudia Rodrigues da Costa Sales ${ }^{2, \text { (iD) }}$

Victor Hugo Gomes Sales ${ }^{4, \text { (D) }}$

* Corresponding author:

paulosales@ifto.edu.br

1 Instituto Federal do Tocantins (IFTO)

2 Universidade Federal do Tocantins (UFT)

3 Universidade Federal de São Carlos (UFSCAR)

4 Instituto Federal do Amapá (IFAP)

\section{Additional information}

Received: 04/05/2016

Accept: 11/21/2016

Published: 12/20/2016

Editor:

Vinicius Batista Campos

Federal Institute of Amapá, Macapá, AP

vinicius.campos@ifap.edu.br

\section{Double blind peer review}

Reviews process

Prot. 1022016R02 (Brazil)

Prot. 1022016R03 (Brazil)

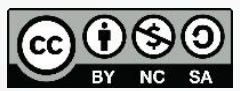

JBFS all rights

Copyright: (c) 2016

\begin{abstract}
ID JBFS1022016
DOI 10.18067/jbfs.v3i4.102

\section{ABSTRACT}

Soybean grains have a high protein content, which can vary depending on various factors, as the pods' position throughout the plant. In this sense, aiming to study the effect of pods' position on the main stem of the plant for grades of soybean proteins, It has been accomplished in the years 2010 and 2011, a trial with ten soybean cultivars in the experimental area of the Federal University of Tocantins in Palmas. The experimental area was randomized blocks with 30 treatments and three replications. Treatments were arranged in one a split plot, being allocated in Ten cultivars plots (BRS Valiosa, P98Y51, P98Y70, P99R03, M8527RR, M8925RR, M9144RR, M8867RR, and TMG103RR), and the sub plots In the pods' position on the plant (upper third, intermediate, and basal third). According to the results, we can conclude that there is variability among the pods' position. The grains located in the median and apical plant showed a trend of higher protein content. Cultivar P98Y70 showed the highest protein value. In the sampling grain for protein quantitation, it is recommended to use grains of pods located at the same position of the plant.
\end{abstract}

Keywords: Sampling. Glycine max. Protein content. grain.

\section{RESUMO}

Os grãos de soja apresentam alto teor protéico, que pode variar em função de diversos fatores e, dentre esses, cita-se o posicionamento das vagens ao longo da planta. Neste sentido, com objetivo de estudar o efeito da posição das vagens na haste principal da planta, quanto aos teores de proteína dos grãos de soja, foi realizado no ano agrícola 2010/11, um experimento com dez cultivares de soja na área experimental da Universidade Federal do Tocantins em Palmas. O delineamento experimental utilizado foi de blocos casualizados, com 30 tratamentos e três repetições. Os tratamentos foram dispostos em um esquema de parcelas subdivididas, sendo alocado nas parcelas dez cultivares (BRS Valiosa, P98Y51, P98Y70, P99R03, M8527RR, M8925RR, M9144RR, M8867RR, TMG103RR e TMG115RR) e nas subparcelas o posicionamento das vagens na planta (terço superior, terço intermediário e terço basal). De acordo com os resultados encontrados, pode-se concluir que existe variabilidade entre as cultivares e entre as posições das vagens. Os grãos localizados na região mediana e apical da planta apresentaram uma tendência de maiores teores de proteína. A cultivar P98Y70, apresentou o mais alto valor proteico. Na amostragem de grãos para quantificação do teor de proteína, recomenda-se utilizar grãos de vagens localizadas na mesma posição da planta.

Palavras-chave: Amostragem. Glycine max. Conteúdo protéico. Grãos 


\section{INTRODUTION}

Soybean (Glycine max (L) Merril) is one of the most important oilseed cultivated worldwide ${ }^{1,2}$. In the harvest 2012/2013, world production reached 267.9 million tons, with a planted area of 108.7 million hectares. Among the producing countries in the 2012/2013 crop, United States deserve to be highlighted with a production of 82.6 million tonnes in acreage: 30.8 million hectares, containing the equivalent of $2.679 \mathrm{~kg} \mathrm{ha}^{-1}$. With a large increase in production yield, it is necessary to emphasize Brazil with a production of 81.5 million tons in an area of 27.7 million hectares planted with productivity of 2.939 kg.ha ${ }^{-1}$, exceeding the United States. ${ }^{3}$

In Brazil, soy is considered a commodity of great commercial importance to the economy, occupying large tracts of planted area in the savannah region. ${ }^{4}$ For Peluzio et al. ${ }^{5}$ Tocantins possesses advantages in the exceeding the United States regarding to other states, as favorable climatic conditions, abundant water resources, and favorable geographical location.

Soy protein has been used for human food, for animal feed, as fertilizer, fiber manufacturing, coatings, paper manufacturing and water emulsion for paints for paints. ${ }^{6}$ According to Vello and Silva, ${ }^{7}$ protein bran is one of the economic factors of paramount importance for soybean. Thus, the elevated socioeconomic value of cultivation is mainly driven to the high protein content ( $40 \%$, on average), allied to a high grain productivity ( $3,000 \mathrm{~kg} \mathrm{ha}^{-1}$ on average).

Protein content might still vary according on climatic conditions ${ }^{8,9}$, Cultivars ${ }^{10}$, fertilization levels ${ }^{11-13}$, leaf removal and pods ${ }^{14}$, shading ${ }^{14,15}$; and pods' position in the main stem of the plant ${ }^{15-19}$.

Regarding the effect of pods' position in the main stem of the plant, numerous $v$ indicated that the grains located on the top of the plant has higher protein concentration than grains from the bottom of the plant ${ }^{15-17}$. On the other hand, a survey conducted by Huskey et al. ${ }^{20}$ reported there was no significant difference in protein content for soybean grain between the upper third of and lower third of the plant which, in turn, were higher than the intermediate third.

Thus, in breeding programs in order to identify cultivars with higher protein content, grain sampling ought to be performed in localized pods in the same position of plant, ie, in the principle of lower third

In this sense, given the scarcity of studies on the grain protein content, according on the pods' location on the main stem of the plants in cultivated soybeans in low latitude, this paper takes place.

\section{MATERIAL AND METHODS}

In crop year 2010/11 an experiment with ten soybean cultivars in the experimental area of the Federal University of Tocantins Palmas-TO (altitude 220 m, 1045'S and $47014 ' \mathrm{~W}$ in soil type Latosol Yellow-Red distrophyc). Sowing was held on December $1^{\text {tt }}, 2010$. The averages of temperature and rainfall during the crop cycle were 25.8 o $\mathrm{C}$ and $750 \mathrm{~mm}$, respectively.

The experimental design utilized was a complete randomized block design with 30 treatments and three replications. The treatments were arranged in a split-plot scheme, being allocated in the plots ten cultivars of determinated growth habit and transgenic (BRS Valiosa, P98Y51, P98Y70, P99R03, M8527RR, M8925RR, M9144RR, M8867RR, TMG103RR e TMG115RR) and at the sub-plots the pods' position on the plant (top third, middle third and inferior third). The choice of these cultivars became because of the adaptation to endafoclimatics conditions in the central region of Tocantins and the inexistence of improved cultivars for high protein content to this region.

The experimental plot consisted in four rows with of $5.0 \mathrm{~m}$ length with soybean plants, spaced between rows $0.45 \mathrm{~m}$. At harvest, were used plants of the two central rows, discarding $0.50 \mathrm{~m}$ the extremity of each-row.

One plowing were performed, with disking and one furrow. Sowing fertilization, performed after analysis of soil and under the requirements of the crop, was $400 \mathrm{~kg} \mathrm{ha}^{-1}$ of NPK 05-25-15. One topdressing fertilization was also performed in stage $\mathrm{R}_{2}$ (full flowering) with $100 \mathrm{~kg} \mathrm{ha}^{-1} \mathrm{~K}_{2} \mathrm{O}$, using as a source potash chloride.

Seeding density was performed to obtain 14 plants per meter with thinning, when necessary, at 10 days after emergence. At the moment of sowing, there was grains' treatment with fungicides (carboxin + thiram $200 \mathrm{SC}>2.5$ $\mathrm{mL}$ of water $+2.5 \mathrm{~mL} \mathrm{~kg}^{-1}$ ), followed by inoculation with Bradyrhizobium japonicum, using the product Biomax ${ }^{\circledR}$ Premium Peat-Soy (strains 5079 and 5080) at a dosage of 60 g $50 \mathrm{~kg}^{-1}$ of soybean seeds. Pests, diseases and weeds control was carried as deemed necessary. For pest control it was used the Methamidophos product (300 $\left.\mathrm{g} \mathrm{ha}^{-1}\right)$, in the stadiums R2, R4 and R6. For assiatic rust control of soybean, it was used two applications of fungicide Tebuconazole 200 CE (0.5L. ha $\left.{ }^{-1}\right)$, one in the R2 stadium and another in R4. Weeds were controlled with an application of Roundup Ready in V6 and R2 stages of soybean at dose of 1.44 L ha-1.

In each experimental plot, in two central rows, 30 plants were harvested. Of each plant were collected from the main stem of three pods containing at least two grains each at the R8 stage of the scale ${ }^{21}$ being the first pods nearest the soil (basal pod $\rightarrow$ bottom third) the second pods in the intermediate position (central pods $\rightarrow$ mediddle third) and 
the pods third of on the plant apex (apical $\rightarrow$ top third) (Figure 1), totaling 90 pods per plot, 30 basal pods 30 pods central, and of 30 apical pods.

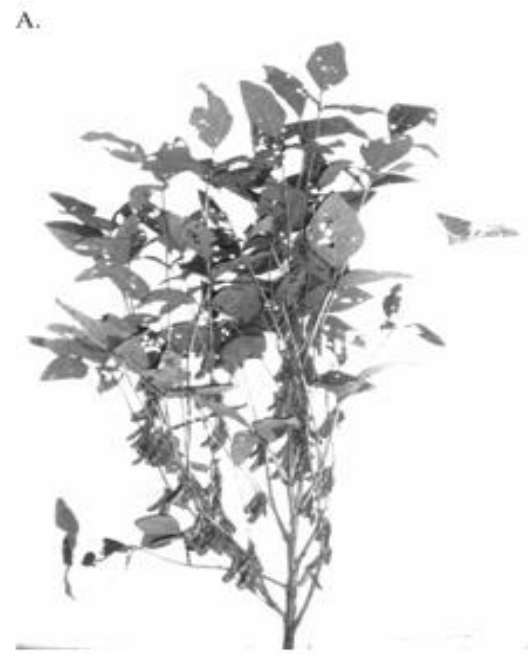

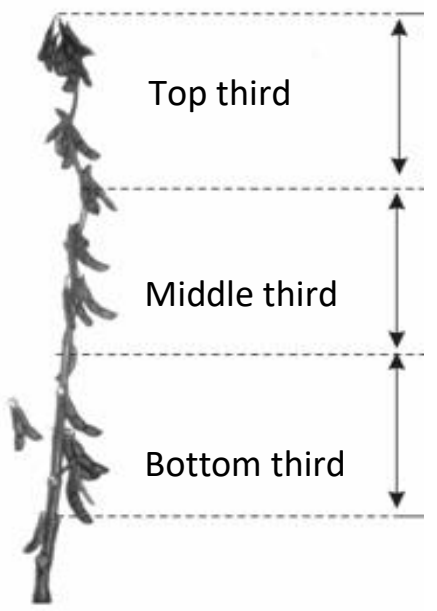

Source: Sales ${ }^{19}$

Figure 1 - Representation of the plant harvested in the experimental field (A) and the section of the plant thirds (bottom, middle and top) from the insertion of the first and final pod of the plant (B).

Then the 30 pods of each position of plot were threshed and the grains put into one paper bag, which was identified by cultivar and pods' position, and transported to the Laboratory of the Agricultural Research -LPA of Food Engineering Course at the Federal University of Tocantins, Palmas Campus, where the milling of grain was held.

After milling the grains, protein content was determined utilizing the method of Kjedhal realized the conversion of the $\% \mathrm{~N}$ into $\%$ protein by a factor of 6.25 for cereal and oilseeds was determined according to the technique of Adolfo Lutz Institute ${ }^{22}$.

With characteristics data of the characteristics, it was held the analysis of variance using the statistical software ASSISTAT VERSION 7.6 BETA (UFPB. 2011). Data of \% protein were submitted to Kolmogorov-Smirnov normality test. Subsequently, the treatment means were compared by Scott Knott test at 5\% significance level.

\section{RESULTS AND DISCUSSION}

Analysis of variance (Table 1) showed significant effects of protein content effect to cultivate, pods' position, and cultivate $\mathrm{x}$ pods' position. A significant interaction cultivar $\mathrm{x}$ pods' position indicates a differential behavior of cultivars, Regarding to the pods' position. Thus, it was realized an unfolding to identify such differences. The coefficients of variation were low, indicating good accuracy of the experiment.

Table 1. Summary of analysis variance for protein content (\%) of 10 soybean cultivars, crop year 2010/11

\begin{tabular}{lcc}
\multicolumn{1}{c}{ Source of Variation } & Degree of Freedom & Medium Square \\
& 2 & Protein Content \\
\hline Block & 9 & $12,64^{*}$ \\
Cultivar (Ta) & 18 & $17,79^{*}$ \\
Residue - (a) & 2 & 2,94 \\
Positions the Pods (Tb) & 18 & $4,05^{*}$ \\
Cultivar x position of the pod & 40 & $8,89 *$ \\
Residue - (b) & - & 1,23 \\
\hline CV\%-a & - & 4,2 \\
\hline CV\%-b & - & 2,7 \\
\hline AVERAGE & - & 41,3
\end{tabular}


The average protein content of the cultivars in different Pods' position is found in Table 2. For the TMG103RR, and M8867RR cultivars, two groups of averages were formed, being the group with the highest protein content present in the medium and apical positions. For the other cultivars, it was not detected significant differences between the pods' position on the main stem although in magnitude, a higher average protein content was observed for middle and top position.

Table 2. Average protein content of ten cultivars of the soybean crop 2010/11 under different pods' position on the main stem of the plant.

\begin{tabular}{ccccc}
\hline \multirow{2}{*}{ CULTIVATE } & \multicolumn{4}{c}{ PODS' POSITION ON THE MAIN STEM } \\
\cline { 2 - 5 } & BOTTOM THIRD & MIDDLE THIRD & TOP THIRD & AVERAGE \\
\hline BRS VALIOSA & $42,3 \mathrm{bA}$ & $42,5 \mathrm{bA}$ & $43,4 \mathrm{aA}$ & 42,7 \\
M8527 RR & $41,0 \mathrm{cA}$ & $41,4 \mathrm{cA}$ & $42,3 \mathrm{aA}$ & 41,6 \\
P98Y51 & $39,6 \mathrm{cA}$ & $40,4 \mathrm{cA}$ & $41,2 \mathrm{bA}$ & 40,4 \\
TMG103 RR & $38,7 \mathrm{cB}$ & $41,3 \mathrm{cA}$ & $40,9 \mathrm{bA}$ & 40,3 \\
P98Y70 & $44,4 \mathrm{aA}$ & $44,6 \mathrm{aA}$ & $42,7 \mathrm{aA}$ & 43,9 \\
M8867 RR & $39,2 \mathrm{cB}$ & $41,5 \mathrm{cA}$ & $41,1 \mathrm{bA}$ & 40,6 \\
M8925 RR & $40,2 \mathrm{cA}$ & $41,1 \mathrm{cA}$ & $41,7 \mathrm{aA}$ & 41,0 \\
TMG115 RR & $42,3 \mathrm{bA}$ & $42,1 \mathrm{bA}$ & $42,2 \mathrm{aA}$ & 42,2 \\
P99R03 & $39,7 \mathrm{cA}$ & $38,6 \mathrm{dA}$ & $38,5 \mathrm{cA}$ & 38,9 \\
M9144 RR & $40,8 \mathrm{cA}$ & $41,1 \mathrm{cA}$ & $40,5 \mathrm{bA}$ & 40,8 \\
\hline AVERAGE & 40,8 & 41,5 & 41,4 & - \\
\hline
\end{tabular}

Averages followed by the same letter uppercase in the lines, and lowercase in columns belong to the same group, by the Scott-Knott test at $5 \%$ significance.

Minors concentration of protein in the basal region of the plants are due to a lower photosynthetic leaves' activity of this region, by the effect of shading ${ }^{15}$ as well as leaf senescence of this region ${ }^{23}$, during the grain filling stage, resulting in a smaller nitrate assimilation, and consequently a lesser protein synthesis.

It is emphasized that the higher protein content of the grain in the middle and apical portions of the plant may be associated with increased accumulation of $\beta$-conglycinin protein component (7S), compared to glycinin the component of (11s), since in these regions during the seed development, there is an increase in the nitrogen / sulfur ratio, which provides a preferential accumulation of $\beta$ conglycinin. ${ }^{24}$ Bennett et al. ${ }^{17}$ at the study about the distribution of these components of the proteins in grains harvested in different parts of the plant, verified that the grains harvested from the top portion of the plant had four times more $\beta$-conglycinin that originating from the bottom portion of the plant.

According to Harper ${ }^{25}$ and Proulx and $\mathrm{Naeve}^{14}, \mathrm{~N}_{2}$ fixation is entirely dependent on energy provided by photosynthesis which, according to Burton ${ }^{26}$, positively influences on grain yield and protein content of the grain.

There was a $0.6 \%$ reduction in the protein content of grain from the top (41.4\%) compared with those found in the bottom part of the plant (40.8\%). These results are in agreement with those obtained by Collins and Cartter ${ }^{16}$, who observed that the grains of the bottom part of the plants were about $1 \%$ lower compared to the protein localized in the top.Saleset. al ${ }^{19}$, Bennettetal. ${ }^{17}$, Naoe etal., ${ }^{23}$ Bellalou and Gillen ${ }^{15}$ also found, 3.03\%, 4.0\%, 5.7\% and $2.48 \%$ variation of protein between the upper middle third of the plants and the third lower.

On the other hand Huskey et al. ${ }^{20}$ found no significant difference in protein concentration between the upper third, lower third, and being who in the middle third of the plant, the grains presented a lower protein concentration relative to other positions.

Significant differences were detected among cultivars within each position for protein content, represented by different groups (Table 2).

For the bottom and middle part, the cultivar P98Y70 reached the highest protein value with, respectively, $44.4 \%$ and $44.6 \%$, followed by cultivars TMG 115 RR (42.3\% and 42.1\%), and BRS Valiosa ( $42.3 \%$ and $42.5 \%$ ) for the basal and middle positions, respectively. The remaining cultivars or roughly $70 \%$ of studied materials belong to a group with minors average protein content in both positions. The cultivar P99R03 (39.7\%) did not differ statistically from other cultivars, for the bottom part, and occupied the singly group with the lowest average for central part on the main stem of the plant. 
In the apical region of the plant, three groups of average were formed. The group with the highest average was represented by BRS Valiosa (43.35\%), P98Y70 (42.70\%), M8527RR (42.30\%), TMG115 RR (42.16\%). The cultivar P99R03 (38.5\%) showed a lower protein content value at the central part. The other cultivars showed intermediate values.

The average protein content of the cultivars ranged from 38.6\% (P99R03) to 43.9\% (P98Y70). These results are in agreement with those obtained by Zanon ${ }^{27}$, whose protein ranges from $30 \%$ to $45 \%$ by Bennett et al. ${ }^{17}$, ranging from $36 \%$ to $40 \%$ and Bellalou and Gillen ${ }^{15}$, ranging from $40 \%$ to $48.6 \%$.

Thus, in the quantification of the protein content of grain in different soybean cultivars, the sampling should preferably be conducted in grains located in the same region of the plant in order to avoid possible errors.

\section{CONCLUSIONS}

There is variability between the pods' position the protein content in the grain.

Grains located in the central, and apical region of the plant showed a trend towards of higher protein levels.

The cultivar P98Y70, submitted the highest protein value in grains in all parts of the plants.

In the sampling of grain for the quantification of protein content, it is recommended to use grains come from pods located in the same position of the plant.

\section{ACKNOWLEDGEMENTS}

The Federal University of Tocantins - Campus Palmas, to Federal Institute of Education, Science and Technology Campus Paraíso do Tocantins, and Coordination of Improvement of Higher Education Personnel (PNPD/CAPES), which have contributed to the realization of this research.

\section{AUTHOR CONTRIBUITION}

The author Paulo Victor Gomes Sales and Victor Hugo Gomes Sales - Conduction of the experiment, analysis the results and wrote the paper;

Ana Cláudia Rodrigues da Costa Sales - Support wrote the paper;

Flávio Sérgio Afférri-Support in the design and conduct of the experiment;

Joenes Mucci Pelúzio - Idealized of the experiment, analyzed the results and reviewed the paper.

\section{COMPETING INTERESTS}

The authors declare there are no competing interests.

\section{FUNDING}

The authors received no funding this work.

\section{HOW TO CITE THIS ARTICLE}

\section{ABNT}

SALES, Paulo Victor Gomes et al. Effect of pods' position on the protein content in soybean grains at low latitude. Journal of bioenergy and food science, v.3, n.4, p.216-221, 2016. DOI:10.18067/jbfs.v3i4.102.

\section{APA}

Sales, PVG., Pelúzio, JM., Afférri, FS., Sales, VHG. \& Oliveira Júnior (2016). Effect of pods' position on the protein contente in soybean grains at low latitude. Journal of Bioenergy and Food Science, 3(4), p.216-221. DOI:10.18067/jbfs.v3i4.102

\section{REFERENCES}

(1).EDMAR, V.S., REIS M. S.,SEDIYAMAT. Análise não-paramétrica da sanidade de sementes e índices de eliminação e classificação de genótipos de soja. Pesquisa Agropecuária Brasileira. v.43, n.3, p.341 $348,2008$.

(2).CLEMENTE, T.E.; CAHOON, E.B. Soybean Oil: Genetic Approaches for Modification of Functionality and Total Content. Plant Physiology, Lincoln, v.151, n.3, p.1030-1040, 2009. DOl:10.1104/pp.109.146282

(3).EMBRAPA - Empresa Brasileira de Pesquisa Agropecuária Embrapa Soja. Soja na alimentação [inemet]. Londrina; Disponível em:

$<$ http://www.cnpso.embrapa.br/soja_alimentacao/index.php?pagi $\underline{\text { na=23}}>$. Acesso em: 05 jan 2015.

(4).SILVA, M. S. etal. Composição química e valor proteico do resíduo de soja em relação ao grão de soja. Ciência e Tecnologia de Alimentos, v.26, n.3, p.571-576, 2006. DOI:10.1590/S010120612006000300014

(5).PELUZIO, J. M et al.; Comportamento de cultivares de soja no sul do estado do Tocantins. Bioscience Journal, Uberlândia, v. 22, n. 2, p. 69-74, 2006.

(6).EMBRAPA - Empresa Brasileira de Pesquisa Agropecuária. SojaOutros produtos. 2008. Disponível em: http://www.cnpso.embrapa.br/html/outros.htm. Acesso em: 14 dez. 2012.

(7).VELLO, N.A.; SILVA, LA.S. Genética busca atender ao consumo humano crescente. Visão Agrícola, v.3, n.5, p.60-62, 2006.

(8).ALBRECHT, L.P.; BRACCINI, A.L.;ÁVILA, M.R.;SUZUKI, LS.;SCAPIM, C.A.; BARBOSA, M.C. Teores de óleo, proteínas e produtividade de soja em função da antecipação da semeadura na região oeste do Paraná. Bragantia, Campina, v. 67, n. 4, p.865-873, 2008. DOI:10.1590/S0006-87052008000400008

(9).BARBOSA, V.S.; PELUZIO, J.M.; AFFÉRRI, F.S.; SIQUEIRAS, G.B. Comportamento de cultivares de soja, em diferentes épocas de 
semeaduras, visando a produção de bicombustível. Revista Ciência Agronômica, Fortaleza, v.42, n.3, p.742-749, 2011.

(10).SOUZA, L.C.F.;ZANON, G.D.; PEDROSO, F; ANDRADE, L.H.L. Teor de proteína e de óleo nos grãos de soja em função do tratamento de sementes e aplicação de micronutrientes. Ciência e Agrotecnologia. Lavras, v.33, n.6, p.1586-1593, 2009. DOI:10.1590/S141370542009000600018

(11).MORAES, L.M.F.; LANA, R.M.Q.; MENDES, C.; MENDES, E.; MONTEIRO, A.; ALVES, J.F.; Redistribuição de molibdênio aplicado via foliar em diferentes épocas na cultura da soja. Ciência e Agrotecnologia, v.32, n.5, p.1496-1502, 2008. DOl:10.1590/S141370542008000500021

(12).TOLEDO, M. Z et al. Nodulação e Atividade do Nitrato Redutase em Função da Aplicação de Molibdênio em Soja. Bioscience Journal, v. 26, n. 6, p.858-864, 2010.

(13).VEIGA, A.D.; PINHO, É.V.R.V.; VEIGA, A.D.; PEREIRA, P.H.A.R.; OLIVEIRA, K.C.; PINHO, R.G.V. Influência do potássio e da calagem na composição química, qualidade fisiológica e na atividade enzimática de sementes de soja. Ciência e Agrotecnologia, v.34, n.4, p.953-960, 2010. DOI:10.1590/S1413-70542010000400022

(14).PROULX, R.A.; NAEVE, S.L (2009). Pod removal, shade, and defoliation effects on soybean yield, protein and oil. Agronomy Joumal, v.101, n.4, 2009, p.971-978. DOI:10.2134/agronj2008.0222x

(15).BELLLOUI, N; GILEN, AM. Soybean seed protein, oil, fattyacids, $\mathrm{N}$, and $\mathrm{S}$ partitioning as affected by node position and cultivar differences. Agricultural Sciences, Stoneville, USA, v.1, n.3, p.110-118. 2010. DOI:10.4236/as.2010.13014

(16).COLUNS, F.I.; CARTTER, J.L; Variability in chemical composition of seed from different portions of the soybean plant. Agronomy Joumal, v.48, n. 5, p.216-219, 1956.

(17).BENNETT, J. O. KRISHNAN, A. H.; WIEBOLD, W. J.; KRISHNAN, H. B. Positional Effect on Protein and Oil Content and Composition of Soybeans. Agricultural and Food Chemistry, Columbia, v. 51, n. 23, p. 6882-6886. 2003. DOI:10.1021/jf034371|
(18).SALES, P.V.G. PELÚZIO, J.M.; AFFÉRRI, F.S.; SILVA, M.C.C.; SALES, V.H.G. Variabilidade da posição das vagens quanto ao teor de óleo em grãos de soja. Revista Ciências Agrárias, v. 56, n. 03, p. 274-277, 2013. DOI:10.4322/rca.2013.042

(19).SALES, V.H.G.; PELÚZIO, J.M.; AFFÉRRI, F.S.; OLIVEIRA JÚNIOR, W.P.; SALES, P.V.G. Teor de óleo e proteína em grãos de soja em diferentes posições da planta. Revista Agroambiente, v.10, n.1, p.22 29, 2016. DOI:10.18227/1982-8470ragro.v10i1.2462

(20).HUSKEY, L. L; SNYDER, H. E.; GBUR, E. E.; Analysis of single soybean seeds for oil and protein. Journal of the American Oil Chemists' Society, v. 67 n.10, p.165-167, 1990. DOI:10.1007/BF02540423

(21).FEHR, W.R.; CAVINESS, C.E.; BURMOOD, D.T.; PENNINGTON, J.S. Stage of development description for soybean (Glycine max (L) Merril).Crop Science, Madson, v.11, n. 6, p.929-931, 1971.

(22).INSTITUTO ADOLFO LUTZ. Normas analíticas do instituto Adolfo Lutz. Métodos químicos e físicos para analise de alimentos. IAL São Paulo. São Paulo:v.1. Ed IV.; 2005.317 p

(23).NAOE, L. K. etal. Avaliação do Teor de Proteína nas Sementes de Diferentes Partes da Planta de Soja. Revista Ciência Agroambiental, v.1, n. 10, p.69-73, 2006.

(24).KRISHNAN, H. B.; JIANG, G.; KRISHNAN, A. H.; WIEBOLD, W. J. Seed storage protein composition of non nodulating soybean (Glycine max L) and its influence on protein quality. Plant Science. Columbia, v.157, n.7, p. 151-199. 2000. DOI:10.1016/S01689452(00)00283-1

(25).HARPER, J.E. Nitrogen metabolism. In J.R. Wilcox (ed.) Soybeans:Improvement, production, and uses. 2nd ed. ASA, CSSA, and SSSA, Madison, WI. 1987. p. 497-533.

(26).BURTON, J. W. Effects of increase light on soybean seed yield and protein concentration. In: WORD SOYBEAN RESEARCH CONFERENCE, 5., 1994, Chiang Mai. Proceedings..Chiang Mai. Kasetsart University Press, 1994. p362-366.

(27).ZANON, G. D. Teor de proteína e de óleo em grãos de soja sob diferentes tipos de manejo. 2007. 62f. Tese (Doutorado) Universidade Federal da Grande Dourados, Dourados, Ms, 2007. 